\title{
Application of permanganate, copper sulfate to the coagulation dose and use of Moringa oleifera seeds as a natural coagulant in water treatment plants to remove algae
}

\author{
Adel H. Abouzied ${ }^{1}$ and Hanan A. S. Hassan ${ }^{2}$ \\ ${ }^{I}$ Central laboratories, the holding company for water and waste-water treatment, Giza, Egypt. \\ ${ }^{2}$ Botany Department, Faculty of Science, Fayoum University, Fayoum, Egypt.
}

\begin{abstract}
:
In Egypt, the Nile River is inhabited by various phytoplankton species through the whole period of examination. In all months, diatoms dominated other groups by numbers, Diatoms numbers of Nile water ranged between 1450 and $11880 \mathrm{Unit} / \mathrm{ml}$; this was followed by green algae which ranged between 700 and $1220 \mathrm{Unit} / \mathrm{ml}$, while the lowest number was observed for blue-green algae which ranged between 160 and 703 Unit/ml. Treatment of Nile water using two chemical coagulants, namely, aluminum sulfate $\left(\mathrm{Al}_{2}\left(\mathrm{SO}_{4}\right)_{3} .16 \mathrm{H}_{2} \mathrm{O}\right)$ and aluminum oxide $\left(\mathrm{Al}_{2} \mathrm{O}_{3}\right)$ removed algae by about $85 \%$ and $90 \%$, respectively, on the addition of a permanganate $\left(\mathrm{KMnO}_{4}\right)$ dose between 0.4 and 1.0 $\mathrm{mg} / \mathrm{l}$ to the applied coagulant dose removed algae by about $92.5 \%$ and $97.2 \%$, respectively, as well as reduced the chlorine dose and the residual aluminum concentration in the treated water. Also, the addition of a Copper (II) sulfate $\left(\mathrm{CuSO}_{4}\right.$ instead of permanganate) dose between 0.25 and $1.0 \mathrm{mg} / \mathrm{l}$ to the applied coagulant dose removed algae by about $93.8 \%$ and $98.1 \%$, respectively. Moringa oleifera seeds present a viable alternative natural coagulant, which raises the removal efficiency for the algal groups, and algal removal achieved between $92 \%$ and $97 \%$ with a dose between 2 and $8 \mathrm{~g} / \mathrm{l}$. Algae have been classified and identified through the comparative morphology of algae in identification keys and the Sedgwick-Rafter counting chamber was used to calculate algal numbers.
\end{abstract}

Keywords: Algal count, Permanganate, Copper sulfate, Chlorine, Moringa oleifera, Water treatment.

\section{Introduction}

The availability of healthy drinking water is crucial in preventing the spread of many water-transmissible diseases. Water treatment authorities are interested in algae, particularly those belonging to the cyanobacteria family; because they produce the taste and odor compounds as well as natural toxins as a 
result of their exposure to certain environmental conditions (Abd El-Hady, 2014; Ahmed, 2016). They also obstruct the production of drinking water by interfering with some water treatment methods. Diatoms typically cause filter obstructions, because of their silicon frustules (Shehata et al., 2008).

Algae are dispersed throughout lakes and rivers with relatively low population density; however, their population is vulnerable to rapid growth as nutrients increase in surface waters (Henderson et al., 2008). This may result in dissolved oxygen depletion, high water turbidity, and ultimately a degradation of the aquatic ecosystem (Manahan, 2000; Abou El Ella et al., 2007; Shen et al., 2011; Wang et al., 2013). Also, this may cause severe disturbance of taste, odor, and excitement of toxins under stressed environmental conditions (Heng et al., 2009; Shen et al., 2011).

Uncontrolled algal blooms can clog screens and rapid sand filters in a conventional water treatment plant, causing the drinking water supply system to be hampered (Babel and Takizawa, 2011; Xuan-Thanh et al., 2019). According to their microscopic size, algae can also penetrate filters and live within storage systems of home drinking water supplies, secreting extracellular organic materials. As a result, microbial regrowth in water delivery systems can be facilitated by weakening the final water disinfection process (Ma and Liu, 2002; Babel and Takizawa, 2011). Finally, to preserve reasonable water quality, it is preferable to eliminate surface water algae during the initial stages of treatment (James and Conrad, 2004; Henderson et al., 2008). This is because removing algal cells as a suspended solid can reduce the soluble toxins associated with them, which could weaken physical and chemical water treatment systems. 
The general strategies for controlling algae in drinking water treatment systems have already been discussed (APHA, 2005; Gao et al., 2010; Devrimci et al., 2012). Coagulation/flocculation is the common method for removing algae since it can extract suspended solids through destabilizing particles, while flocculation allows solid separation by stabilization, flotation, and filtration (James and Conrad, 2004; Henderson et al., 2008; Gao et al., 2010; Shen et al., 2011; Devrimci et al., 2012). On the contrary, Due to their small size and low specific gravity, algae cannot be extracted effectively using chemical coagulation alone (Devrimci et al., 2012; Yanxia Zhao et al., 2021). Since oxidizing chemicals (such as chlorine, permanganate, and copper (II) sulfate) have the potential to disrupt algal cells, they are needed to improve coagulation (Chen and Yeh, 2005; Heng et al., 2009 ; Gao et al., 2010).

Many species require copper as a micronutrient. However, its absence leads to a decrease in the functioning of the enzyme systems, and disorder of metabolism in the body. Copper is also a component of plastocyanin or the chloroplast in the protein responsible for electronic transport during photosynthesis. In the case of plants, it occurs in a large number of chloroplasts (El-Dars et al., 2015). Nitrogen and carbohydrate metabolism is involved in oxidation-reducing reactions, responsible for the correct pathway of photosynthesis and respiration. Also, excessive copper contents are toxic (ElDars et al., 2015). Potassium permanganate has been examined as a pre-oxidant alternative to improve direct filtration of retained surface water.

The Jar tests and experiments conducted by a pilot plant showed that pre-treatment of permanganate or copper (II) sulfate followed by coagulation greatly improved the removal of particles and algae (Babel and Takizawa, 2011; Badawy et al., 2012; Xuan-Thanh et al., 2019). In general, chlorine is the 
preferred oxidizing substance because it is a powerful disinfectant for water and safer to be applied; more economical than other algaecides, and less timeconsuming in the application (Shen et al., 2011). However, it has been reported that algae may consume large amounts of chlorine and thus reduce the free chlorine available to control bacteria if they continue after treatment (Shen et al., 2011; Mohamed et al., 2020). Moreover, it has been reported that an overdose of oxidizing substances should be avoided because it can cause damage to algal cells and release harmful toxins or offensive taste and odor-related compounds or water-color in case of an overdose (Heng et al., 2008; Shen et al., 2011; Yanxia Zhao et al., 2021).

In Egypt, the typical drinking water treatment system includes phases from pre-chlorination, flocculation/coagulation, filtering (rapid sand filters), and post-chlorination after settling into distribution tanks (Donia, 2007; Mohamed et al., 2020). In this setting, the pre-chlorination stage is the most important stage for controlling the growth of bacteria and algae (El-Shinnawy et al., 2000; Donia, 2007; Badawy et al., 2012). In this regard, several studies have been conducted to investigate the contribution of this stage to the formation of secondary disinfection products in the final treated water and to develop recommendations for their application (El-Shinnawy et al., 2000; Badawy et al., 2012; Ashenafi et al., 2018). However, in a review by Donia (2007), it has been speculated that there is a need to update existing treatment technologies in Egypt to address recently added loads of chemical and biological pollutants transported through surface and drinking water systems.

Multivariate statistical analysis was applied to determine the contribution of the measured parameters to such occurrence. Also, during this work, the study of methods to improve the efficiency of the current applied pre- 
oxidation/coagulation procedure through the use of combined pre-oxidation as permanganate or copper (II) sulfate with chlorine dose and various use was performed the coagulation of aluminum sulfate $\left(\mathrm{Al}_{2}\left(\mathrm{SO}_{4}\right)_{3} \cdot 16 \mathrm{H}_{2} \mathrm{O}\right)$ and aluminum oxide $\left(\mathrm{Al}_{2} \mathrm{O}_{3}\right)$ during the period of algal spread. As a final step, the effect of this combined pretreatment/coagulation upon the final main water parameters and the residual metal (aluminum/iron) concentration in the treated water was assessed using multivariate statistical analysis (Amagloh and Benang, 2009; El-Dars et al., 2015; Xuan-Thanh et al., 2019). Essentially, coagulants are evaluated for two reasons: firstly, to choose the best coagulant in terms of performance, and secondly, to ensure consistent quality of the product (WHO, 2011; Ahmed, 2016).

The use of a natural coagulant from seeds of the Moringa oleifera tree to replace conventional coagulants such as aluminum salts in both domestic and large-scale water treatment is now considered an effective and efficient method of removing undesirable chemicals from contaminated waters. Moringa oleifera seed extract can be used to treat water because the seeds contain protein components that are effective for coagulation (Gautam and Vikram, 2011; Ibrahim et al., 2015; Ashenafi et al., 2018; Xuan-Thanh et al., 2019; Yanxia Zhao et al., 2021).

\section{Materials and Methods}

\section{Description of the sampling sites}

Water samples were collected monthly, for one year. This was at the inlet of Al-Ayat water treatment plant, a rural region, about $55 \mathrm{~km}$ south of Giza 
governorate, west of the River Nile. According to the Egyptian Ministry of Irrigation, 2001, the annual average of Al-Ayat water treatment plant depth was $6.8 \mathrm{~m}$, discharge was $130000 \mathrm{~m}^{3} / \mathrm{day}$. The selecting site of River Nile was far from the industrial stations by about $42 \mathrm{~km}$, at which the water undergoing natural self-purification processes.

Physico-chemical characters, Biological Parameters and Chlorine determination: they were carried out according to Standard methods, (APHA, 2012).

Jar test: Coagulation and flocculation was conducted via the "Jar Test" procedure devised by Cohen, (1957), Bulusu \& Sharma, (1967) and Zeta-Meter, (1993).

Jar test depends on the Alum coagulant dose combine with preoxidation and chlorine dose to reduce algal count; the flash mixing was $120 \mathrm{rpm}$ for $30 \mathrm{sec}$. while the slow mixing was $15 \mathrm{rpm}$ for 15 minutes and settling time was 8 minutes. Aluminum sulfate coagulant $(28 \mathrm{mg} / \mathrm{l})$ with pre-oxidant such as permanganate $(0.4 \mathrm{mg} / \mathrm{l})$ or Copper (II) sulfate $(0.25 \mathrm{mg} / \mathrm{l})$, pre-treatment was followed by coagulation significantly improved the particle and algal removal.

Jar test depends on Moringa oleifera on coagulant doses and chlorine dose to reduce algal count; the flash mixing was $120 \mathrm{rpm}$ for 2 minutes while the slow mixing was $15 \mathrm{rpm}$ for 15 minutes and settling time was one hour. The natural flocculants of Moringa oleifera seeds were tested for coagulation activity against Nile water algae. 


\section{Moringa oleifera seeds extracted method}

The cutting fruits were sliced to obtain seeds that were air-dried for 3 to 7 days. The shells surrounding the seed kernels were removed; the kernels were powdered by laboratory mortar and pestle, and then sieved with a sieve of 2.5 $\mathrm{mm}^{2}$ pore size to obtain a powder. In a dark place, the powder was stored at room temperature in a sterile bottle. First, the powdered sample was extracted simultaneously using methanol or ethanol, acetone, and aqueous in increasing polarity. In this procedure, $50 \mathrm{~g}$ of $M$. oleifera powdered seeds were soaked in 250 $\mathrm{ml}$ of each of the solvents which were acetone, methanol, and aqueous, and in all cases equal volumes of solvents were used. They were left to mix on a horizontal shaker for 3 hours. The oil in the seed powder was removed with solvents for three extraction cycles. Second, extraction with $1.0 \mathrm{~mol} / \mathrm{l} \mathrm{NaCl}$ solution $(250 \mathrm{ml}$ of $1.0 \mathrm{~mol} / 1 \mathrm{NaCl}$ solution per $50 \mathrm{~g}$ of $M$. Oleifera Coagulant) improve the coagulation activity of MOC( Moringa Oleifera Coagulant) extracted with $\mathrm{NaCl}$ solution achieved seven times less turbidity than kaolin solution compared to traditional MOC extracted by distilled water, then the extracts were separately filtered through Whatman No.1 filter paper. The filtrates were centrifuged, at $5000 \mathrm{rpm}$ for $15 \mathrm{~min}$, and each extract supernatant was evaporated by a rotary evaporator (BUCHI Rotavapor R-100 Rotary), and then dried overnight in an oven at $50{ }^{\circ} \mathrm{C}$ (Ashenafi et al., 2018; Xuan-Thanh et al., 2019).

\section{Jar test depends on Moringa oleifera}

Moringa oleifera water samples were dispensed into six beakers, each containing $1000 \mathrm{ml}$. Weighing 2.0, 2.5, 3.0, 3.5, 4.0, and $4.5 \mathrm{gm}$ of M. oleifera seed powder and distilled water blank yielded six different concentrations of the 
stock solution for the applied dose. To achieve a simple solution, the mixtures in the beakers were stirred on the jar test device. As a negative regulation, $1000 \mathrm{~mL}$ of distilled water with no $M$. oleifera seed powder extract was used. Two $\mathrm{ml}$ of the various concentrations including the control of all the applied dosages prepared was measured into a beaker containing $1000 \mathrm{ml}$ of the sample river water. To help in coagulant formation, the solutions were flash mixed for 2 minutes and then slowly mixed for 15 minutes on the jar test device. For one hour, the suspensions were permitted to settle without being interrupted. Since there is no specific procedure for conducting the jar test, this is the preferred method. The supernatants formed were recovered and subjected to Algal count, Turbidity, $\mathrm{pH}$, Alum, Residual Chlorine, EC, TDS (Total Dissolved Salts), Mn, Fe, Chloride, Sulfates, and TOC (Total Organic Carbon) measurements.

Statistical analysis of data: The data were analyzed using the statgraphics (Statistical Graphics Corporation, Princeton, USA) statistical package, which included the t-test and ANOVA functions to assess significant differences among means.

\section{Results and Discussion}

\section{Quantitative estimation of phytoplankton:}

Nile River water included diverse phytoplankton compositions belonging to five main categories, namely, the Pyrrhophyta, Charophyta, Cyanophyta, Chlorophyta and Bacillariophyta were presented through the full period of 
investigation with $1,3,14,23$, and 28 species, respectively, so it may be important to note that diatoms were recorded as an abundant group in all investigated samples (Table 1).

Table 1: The distribution of algal species in Nile samples.

\begin{tabular}{|c|c|c|c|}
\hline Algal Species & Occurrence & Algal Species & Occurrence \\
\hline Chlorophyta & & Microcystis aeruginosa Kützing & + \\
\hline $\begin{array}{l}\text { Actinastrum hantzschii } \\
\text { Lagerheim }\end{array}$ & + & $\begin{array}{l}\text { Oscillatoria limnetica } \\
\text { Lemmermann }\end{array}$ & + \\
\hline $\begin{array}{l}\text { Ankistrodesmus acicularis var. } \\
\text { mirabilis }\end{array}$ & + & Spirulina allansonii Welsh & + \\
\hline Botryococcus braunii Kützing & + & $\begin{array}{l}\text { Planktothrix rubescens } \\
\text { Anagnostidis \& Komárek }\end{array}$ & + \\
\hline $\begin{array}{l}\text { Chodatella cilliata Lagerheim } \\
\text { Chlamydomonas ehrenbergii } \\
\text { Gorozhankin }\end{array}$ & $\begin{array}{l}+ \\
+\end{array}$ & Total Cyanophyta species & 14 \\
\hline Chlorella regularis Oltmanns & + & Bacillariophyta & \\
\hline Coelastrum microporum Nägeli & + & $\begin{array}{l}\text { Amphora ovalis var. minor } \\
\text { Kützing }\end{array}$ & + \\
\hline $\begin{array}{l}\text { Crucigenia rectangularis } \\
\text { Nägeli }\end{array}$ & + & Asterionella formosa Hassall & + \\
\hline $\begin{array}{l}\text { Dictyosphaerium } \\
\text { ehrenbergianum Nägeli }\end{array}$ & + & $\begin{array}{l}\text { Cocconeis placentulaf. major } \\
\text { Cleve }\end{array}$ & \\
\hline Golenkinia radiata Chodat & + & $\begin{array}{l}\text { Cyclotella comta var. bodanica } \\
\text { Grunow }\end{array}$ & + \\
\hline $\begin{array}{l}\text { Kirchneriella obesa var. } \\
\text { contorta Schmidle }\end{array}$ & + & Cyclotella catenata Bachmann & + \\
\hline $\begin{array}{l}\text { Micractinium pusillum } \\
\text { Fresenius }\end{array}$ & + & Cymbella prostrata Cleve & + \\
\hline
\end{tabular}




\begin{tabular}{|c|c|c|c|}
\hline Nephrocytium lunatum West & + & Diatoma elongata Lyngbye & + \\
\hline $\begin{array}{l}\text { Oocystis parva West \& } \\
\text { G.S.West }\end{array}$ & + & $\begin{array}{l}\text { Diatoma vulgaris var. producta } \\
\text { Grunow }\end{array}$ & + \\
\hline Oocystis solitaria f. major Wille & + & $\begin{array}{l}\text { Fragilaria capucina var. } \\
\text { familiaris }\end{array}$ & + \\
\hline $\begin{array}{l}\text { Pediastrum clathratum } \\
\text { Lemmermann }\end{array}$ & + & $\begin{array}{l}\text { Gomphonema olivaceum } \\
\text { Brébisson }\end{array}$ & + \\
\hline Pediastrum simplex Meyen & + & $\begin{array}{l}\text { Gyrosigma attenuatum } \\
\text { Rabenhorst }\end{array}$ & + \\
\hline Cryptomonas erosa Ehrenberg & + & Melosira granulata Ralfs & + \\
\hline Scenedesmus obliquus Turpin & + & Navicula bacillum Ehrenberg & + \\
\hline $\begin{array}{l}\text { Scenedesmus quadricauda } \\
\text { Chodat }\end{array}$ & + & $\begin{array}{l}\text { Navicula cuspidata var. } \\
\text { alaskaensis Foged }\end{array}$ & + \\
\hline $\begin{array}{l}\text { Sphaerocystis schroeteri } \\
\text { Chodat }\end{array}$ & + & Navicula exigua W.Gregory & + \\
\hline $\begin{array}{l}\text { Tetraedron minimum } \\
\text { Hansgirg }\end{array}$ & + & Navicula mutica f. cohnii Cleve & + \\
\hline $\begin{array}{l}\text { Ulothrix subtilissima } \\
\text { Rabenhorst }\end{array}$ & + & Nitzschia acicularis Kützing & + \\
\hline Total Chlorophyta species & 23 & $\begin{array}{l}\text { Nitzschia closterium } f . \\
\text { minutissima Allen \& Nelson }\end{array}$ & + \\
\hline Charophyta & & $\begin{array}{l}\text { Nitzschia constricta var. major } \\
\text { Grunow }\end{array}$ & + \\
\hline $\begin{array}{l}\text { Closterium acerosum } \\
\text { Ehrenberg }\end{array}$ & + & Nitzschia nana Grunow & + \\
\hline Spirogyra porticalis Dumortier & + & Nitzschia sigmoidea Nitzsch & + \\
\hline $\begin{array}{l}\text { Staurastrum paradoxum Meyen } \\
\text { ex Ralfs }\end{array}$ & + & $\begin{array}{l}\text { Nitzschia hungarica var. linearis } \\
\text { Grunow }\end{array}$ & + \\
\hline Total Charophyta species & 3 & $\begin{array}{l}\text { Nitzschia linearis var. tenuis } \\
\text { Grunow }\end{array}$ & + \\
\hline $\begin{array}{l}\text { Cyanophyta } \\
\text { Anabaena flos-aquae f. major } \\
\text { Elenkin }\end{array}$ & + & $\begin{array}{l}\text { Peridinium cinctum f. areolatum } \\
\text { Pinnularia aequalis Ehrenberg }\end{array}$ & $\begin{array}{l}+ \\
+\end{array}$ \\
\hline
\end{tabular}

Egyptian J. of Phycol. Vol. 22, 2021

- 10 - 


\begin{tabular}{|c|c|c|c|}
\hline Anabaena solitaria Klebahn & + & Stephanodiscus astraea Grunow & + \\
\hline $\begin{array}{l}\text { Anabaena planctonica } \\
\text { Brunnthaler }\end{array}$ & + & Synedra ulna f. danica Hustedt & + \\
\hline Anabaena circinalis filament & + & $\begin{array}{l}\text { Tabellaria fenestrata var. } \\
\text { asterionelloides Grunow }\end{array}$ & + \\
\hline $\begin{array}{l}\text { Anacystis marginata } \\
\text { Meneghini }\end{array}$ & + & Total Bacillariophyta species & 28 \\
\hline $\begin{array}{l}\text { Aphanizomenon flos-aquae var. } \\
\text { gracile Lemmermann }\end{array}$ & + & Pyrrhophyta & \\
\hline Chroococcus turgidus Nägeli & + & Ceratium hirundinella Dujardin & + \\
\hline $\begin{array}{l}\text { Coelosphaerium kuetzingianum } \\
\text { Nägeli }\end{array}$ & + & Total Pyrrhophyta species & 1 \\
\hline $\begin{array}{l}\text { Cylindrospermum stagnale } \\
\text { Bornet \& Flahault }\end{array}$ & + & & \\
\hline $\begin{array}{l}\text { Merismopedia glauca } \\
\text { Ehrenberg }\end{array}$ & + & Total No. of algal species & 69 \\
\hline
\end{tabular}

\begin{abstract}
Algal count:
The grouping of phytoplankton green algae, blue-green algae, and diatoms varied in their numbers in River Nile water during the different months of the study year. In all months diatoms exceed the other groups in numbers, Diatoms numbers of Nile water were ranged between $1.45 \times 10^{6}$ and $1.18 \times 10^{7}$ Unit/l, this was followed by green algae which ranged between $1.22 \times 10^{5}$ and $6.99 \times 10^{5}$ Unit/l, while the lowest number was observed for blue-green algae which ranged between $1.6 \times 10^{3}$ and $7.03 \times 10^{5}$ Unit/l. These results are in
\end{abstract}


agreement with those of Ahmed (2016) and Shehata et al. (2008) who found that green algae, blue-green algae, and diatoms were varied in their numbers.

\begin{abstract}
Algal removal:
Treatment of Nile water using two chemical coagulants, namely, aluminum sulfate $\left(\mathrm{Al}_{2}\left(\mathrm{SO}_{4}\right)_{3} \cdot 16 \mathrm{H}_{2} \mathrm{O}\right)$ and aluminum oxide $\left(\mathrm{Al}_{2} \mathrm{O}_{3}\right)$ removed algae by about $85 \%$ and $90 \%$, respectively, when the addition of a permanganate $\left(\mathrm{KMnO}_{4}\right)$ dose was between 0.4 and $1.0 \mathrm{mg} / \mathrm{l}$ to the applied coagulant dose, it removed algae by about $92.5 \%$ and $97.2 \%$, respectively, as well as reduced the chlorine dose and the residual aluminum concentration in the treated water. Also, the addition of a Copper (II) sulfate $\left(\mathrm{CuSO}_{4}\right)$ dose between 0.25 and $1.0 \mathrm{mg} / \mathrm{l}$ to the applied coagulant dose removed algae by about $93.8 \%$ and $98.1 \%$, respectively. These results are in agreement with the results recorded by El-Dars et al. (2015) who stated that to improve the efficiency of the current applied preoxidation/coagulation procedure through the use of a combined pre-oxidation (permanganate or Copper(II)sulfate and chlorine) and the use of the different coagulants aluminum sulfate and aluminum oxide was undertaken during the algal growth. Also, Moringa oleifera seeds present a viable alternative natural coagulant, which raises the removal efficiency for the five algal groups and algal removal was achieved between $92 \%$ and $97 \%$, with a dose between 2 and $8 \mathrm{~g}$ M.O/l. These results go parallel with Shehata et al. (2008) and Ibrahim et al. (2015) who stated that, Moringa oleifera seeds present a viable alternative natural
\end{abstract}


coagulant, which raises the removal efficiency for algal groups and algal removal was achieved over $97 \%$.

\section{Pre-oxidant:}

Pre-treatment with permanganate or copper (II) sulfate, accompanied by coagulation, greatly improved particle and algae removal.

\section{Permanganate $\left(\mathrm{KMnO}_{4}\right)$ :}

Although the key problem with using chlorine and its derivatives in water purification is the formation of chlorinated by-products, the application of $\mathrm{KMnO} 4$, which has been documented to extract soluble manganese and iron frequently associated with the existence of cyanobacteria in raw water, has been improved (Chen and Yeh 2005; Fan et al., 2013). KMnO4 may also be used to replace pre-chlorination or other oxidants in treatment plants to regulate color, taste, odor, and algae, as well as to better control biological development. Furthermore, previous research has shown that combining chlorine and permanganate during pre-oxidation improves water disinfection. (Heng et al., 2009).

This study recommended using a permanganate dose between 0.4 and 1.0 $\mathrm{mg} / \mathrm{l}$ to improve algae removal by alum coagulation, so the applied coagulation dose removes algae by about $92.5 \%$ and $97 \%$, respectively. Heng et al. (2008) indicated that the permanganate dose of $0.5 \mathrm{mg} / \mathrm{l}$ in combination with chlorine achieved the best efficacy in turbidity reduction and CODMn in raw surface water. In the current study, the effect of adding an optimum constant dose of 0.5 $\mathrm{mg} / \mathrm{l} \mathrm{KMnO}_{4}$ on the demand for aqueous chlorine was studied. 
The results show that the applied dose of permanganate effectively reduced the chlorine demand, and the resulting water retained the acceptable residual chlorine content required to control bacterial growth in the water supply delivery system. This can be explained by the synergistic effect and the strong adsorption power of the low/medium product of permanganate $\left(\mathrm{MnO}_{2}\right)($ Shen et al., 2011). Also, the combination of permanganate/chlorine during the preoxidation stage may enhance the inactivation of algal cells and their removal by coagulation, therefore an event that may control the production of Trihalomethanes (Usepa, 1999; Chen and Yeh, 2009). However, overdoses with permanganate should be avoided because the remaining amount of $0.5 \mathrm{mg} / \mathrm{l}$ $\mathrm{KMnO}_{4}$ or greater may lead to pink staining in drinking water. However, Fan et al. (2013) indicated that applying a dose of $1 \mathrm{mg} / \mathrm{l} \mathrm{KMnO}_{4}$ may result in a remaining $\mathrm{KMnO}_{4}$ of $0.2 \mathrm{mg} / \mathrm{l}$, which becomes undetectable after 1-2 hours of the treatment because of their oxidation. El-Dars et al. (2015) stated that use a permanganate dose between 0.5 and $3 \mathrm{mg} / \mathrm{l}$ improved algal removal by alum coagulation.

Jar test depends on Alum coagulant dose $(28 \mathrm{mg} / \mathrm{l})$ with combined peroxidant permanganate doses (from 0.2 to $1.2 \mathrm{mg} / \mathrm{l}$ ) and chlorine dose $(4.0 \mathrm{mg} / \mathrm{l})$ to reduce algal count in Nile River, when the algal count was 5400 unit $/ \mathrm{ml}$ and turbidity was 9.33 NTU.

The highest algal count (180 Unit/ml) was recorded at $28 \mathrm{mg} / \mathrm{l}$ of alum dose with a combined per-oxidant permanganate $(0.2 \mathrm{mg} / \mathrm{l})$, while the lowest algal count (110 Unit $/ \mathrm{ml}$ ) was recorded at $28 \mathrm{mg} / \mathrm{l}$ of alum doses with a combined peroxidant permanganate $(1.2 \mathrm{mg} / \mathrm{l})$, therefore the optimal dose of alum was detected at $28 \mathrm{mg} / \mathrm{l}$ with a combined per-oxidant permanganate $(0.4 \mathrm{mg} / \mathrm{l})$, at this dose the percentage of algal removal was $97.22 \%$, residual chlorine and alum satisfy for 
colorless drinking water, because overdose and low costs. $\mathrm{pH}$ values as a chemical agent showed that the highest $\mathrm{pH}$ value (7.3), while the lowest $\mathrm{pH}$ value (7.2) was recorded. Turbidity as a physical agent was reduced from 9.33 NTU to 1.43 NTU. Residual alum ranged from 0.09 to $0.13 \mathrm{mg} / \mathrm{L}$, (the normal range should not excessed $0.2 \mathrm{mg} / \mathrm{L}$ ). Residual chlorine ranged from 2.5 to $2.8 \mathrm{mg} / \mathrm{L}$ (Table 2).

Table 2: Jar test depend on alum dose $(28 \mathrm{mg} / \mathrm{l})$ with a combined per-oxidant permanganate doses (from 0.2 to $1.2 \mathrm{mg} / \mathrm{l}$ ) and chlorine dose $(4.0 \mathrm{mg} / \mathrm{l})$ in Nile River samples.

\begin{tabular}{lcccccc}
\hline \multicolumn{1}{c}{ Alum (28mg/L)+ permanganate } & $\begin{array}{c}\mathbf{0 . 2} \\
(\mathbf{m g} / \mathbf{l})\end{array}$ & $\begin{array}{c}\mathbf{0 . 4} \\
(\mathbf{m g} / \mathbf{l})\end{array}$ & $\begin{array}{c}\mathbf{0 . 6} \\
(\mathbf{m g} / \mathbf{l})\end{array}$ & $\begin{array}{c}\mathbf{0 . 8} \\
(\mathbf{m g} / \mathbf{l})\end{array}$ & $\begin{array}{c}\mathbf{1 . 0} \\
(\mathbf{m g} / \mathbf{l})\end{array}$ & $\begin{array}{c}\mathbf{1 . 2} \\
(\mathbf{m g} / \mathbf{l})\end{array}$ \\
\hline $\begin{array}{l}\text { Algal count } \\
\text { (Unit/mL) }\end{array}$ & 180 & 150 & 150 & 130 & 120 & 110 \\
$\mathbf{p H}$ & 7.3 & 7.25 & 7.25 & 7.2 & 7.2 & 7.2 \\
$\begin{array}{l}\text { Turbidity } \\
\text { (NTU) }\end{array}$ & 1.49 & 1.43 & 1.44 & 1.46 & 1.47 & 1.48 \\
$\begin{array}{l}\text { Residual Alum } \\
\text { (mg/L) }\end{array}$ & 0.13 & 0.12 & 0.11 & 0.10 & 0.09 & 0.09 \\
$\begin{array}{l}\text { Residual chlorine } \\
\text { (mg/L) }\end{array}$ & 2.5 & 2.5 & 2.6 & 2.6 & 2.7 & 2.8 \\
\hline
\end{tabular}

\section{Copper sulfate $\left(\mathrm{CuSO}_{4}\right)$ :}

In this study, it is recommended to apply copper sulfate $\left(\mathrm{CuSO}_{4} \cdot 5 \mathrm{H}_{2} \mathrm{O}\right)$ between 0.25 and $1 \mathrm{mg} / \mathrm{l}$ to improve algal removal by alum coagulation. Note that $1 \mathrm{mg} / \mathrm{l}$ of copper sulfate expressed in $\mathrm{CuSO}_{4} \cdot 5 \mathrm{H}_{2} \mathrm{O}$ equals $0.26 \mathrm{mg} / \mathrm{l}$ as $\mathrm{Cu}^{2+}$. The literature indicates that a concentration of 0.05 to $0.10 \mathrm{mg} / \mathrm{l} \mathrm{as} \mathrm{Cu}^{2+}$ is effective in controlling blue-green algae in pure cultures under laboratory conditions. This 
equals 0.2 to $0.4 \mathrm{mg} / \mathrm{l}$ as $\mathrm{CuSO}_{4} \cdot 5 \mathrm{H}_{2} \mathrm{O}$. For field applications, concentrations of $0.26 \mathrm{mg} / \mathrm{l} \mathrm{Cu}^{2+}$ are generally suggested. Too much copper sulfate than necessary is uneconomical and environmentally undesirable (Raman and Raman, 1990). Water treatment plants used copper as an active ingredient to control algae, the most common formula is copper sulfate, and the mechanism occurred when copper dissolved in a solution; free copper ions will kill target organisms, copper precipitate and accumulate in the sedimentation basin. We should not use a copper concentration greater than $1.0 \mathrm{mg} \mathrm{Cu} / \mathrm{l}$ to avoid taste and staining problems in water (Carkal 2002). Copper is a component of many proteins and enzymes involved in a variety of metabolic pathways in plants and algae, so copper toxicity is mainly related to free ions and its sensitivity varies among microalgae (Purbonegoro et al., 2018).

Jar test depends on Alum coagulant dose $(28 \mathrm{mg} / \mathrm{l})$ with a combined Copper sulfate doses (from 0.15 to $0.4 \mathrm{mg} / \mathrm{l})$ and chlorine dose $(4.0 \mathrm{mg} / \mathrm{l}$ ) to reduce algal count in Nile River, when the algal count was $5400 \mathrm{Unit} / \mathrm{ml}$ and turbidity was 9.33 NTU.

The highest algal count (140 Unit/ml) was recorded at $28 \mathrm{mg} / \mathrm{l}$ of alum dose with a combined per-oxidant Copper sulfate $(0.15 \mathrm{mg} / \mathrm{l})$, while the lowest algal count ( $80 \mathrm{Unit} / \mathrm{ml}$ ) was recorded at $28 \mathrm{mg} / \mathrm{l}$ of alum doses with a combined per-oxidant Copper sulfate $(0.4 \mathrm{mg} / \mathrm{l})$, therefore the optimal dose of alum was detected at $28 \mathrm{mg} / \mathrm{l}$ with a combined per-oxidant Copper sulfate $(0.25 \mathrm{mg} / \mathrm{l})$, at this dose the percentage of algal removal was $97.7 \%$, residual chlorine and alum satisfy for colorless drinking water, more than overdose and low costs. $\mathrm{pH}$ values as a chemical agent showed that the highest $\mathrm{pH}$ value (7.4), while the lowest $\mathrm{pH}$ value (7.2) was recorded. Turbidity as a physical agent reduced from 9.33 NTU to 1.33 NTU. Residual alum ranged from 0.10 to $0.14 \mathrm{mg} / \mathrm{l}$, (the normal range 
should not excessed $0.2 \mathrm{mg} / \mathrm{l}$ ). Residual chlorine ranged from 2.1 to $2.5 \mathrm{mg} / \mathrm{l}$ (Table 3).

Table 3: Jar test depend on alum doses ( $28 \mathrm{mg} / \mathrm{l})$ with a combined Copper sulfate doses (from 0.15 to $0.4 \mathrm{mg} / \mathrm{l})$ and chlorine dose $(4.0 \mathrm{mg} / \mathrm{l})$ in Nile River samples.

\begin{tabular}{lccccccc}
\hline \multicolumn{1}{c}{$\begin{array}{c}\text { Alum }(\mathbf{2 8 m g} / \mathbf{L})+(\mathbf{C u S O}) \\
\text { parameters }\end{array}$} & & $\begin{array}{c}\mathbf{0 . 1 5} \\
(\mathbf{m g} / \mathbf{l})\end{array}$ & $\begin{array}{c}\mathbf{0 . 2 0} \\
(\mathbf{m g} / \mathbf{l})\end{array}$ & $\begin{array}{c}\mathbf{0 . 2 5} \\
(\mathbf{m g} / \mathbf{l})\end{array}$ & $\begin{array}{c}\mathbf{0 . 3 0} \\
(\mathbf{m g} / \mathbf{l})\end{array}$ & $\begin{array}{c}\mathbf{0 . 3 5} \\
(\mathbf{m g} / \mathbf{l})\end{array}$ & $\begin{array}{c}\mathbf{0 . 4 0} \\
(\mathbf{m g} / \mathbf{l}\end{array}$ \\
\hline Algal count & $(\mathbf{U n i t} / \mathbf{m L})$ & 140 & 120 & 100 & 100 & 90 & 80 \\
$\mathbf{p H}$ & & 7.4 & 7.3 & 7.25 & 7.25 & 7.2 & 7.2 \\
Turbidity & $(\mathbf{N T U})$ & 1.40 & 1.36 & 1.33 & 1.33 & 1.32 & 1.31 \\
Residual Alum & $(\mathbf{m g} / \mathbf{L})$ & 0.14 & 0.14 & 0.14 & 0.12 & 0.11 & 0.10 \\
Residual chlorine & $(\mathbf{m g} / \mathbf{L})$ & 2.1 & 2.2 & 2.2 & 2.3 & 2.4 & 2.5 \\
\hline
\end{tabular}

\section{Moringa oleifera:}

In recent years, there has been a focus on using appropriate low-cost technology to treat drinking water in developing countries. The presence of various algal groups in large numbers, especially the troublesome shapes, in the Nile River has strengthened the reassessment of traditional treatment techniques (Reckhow, 1986; Jahn, 1988).

This study focused on modified or innovative methods that adequately treat the removal of different types of algae. The treatment of Nile water algae was modified by stopping the use of alum and the use of natural seeds - Moringa oleifera to clear water. Also, the addition of $M$. oleifera doses between 2 and $8 \mathrm{~g} / 1$ was applied as a natural coagulant. The removal of algae from raw Nile water Egyptian J. of Phycol. Vol. 22, 2021 
treated with optimal condition of $M$. oleifera was very high and reached between $92 \%$ and $97 \%$, respectively. It is important to note that, M. oleifera was the most effective coagulant and can remove all algal groups from raw Nile water without pre-chlorination. The seed $M$. oleifera contains a coagulant protein (Nadabigengesere et al., 1995; Gassenschmidt et al., 1995) which can replace conventional coagulant such as aluminum salts, in both domestic and larger scale water treatment suggested that $M$. oleifera seeds can be used as a coagulant in water and wastewater treatment after appropriate purification of positive active proteins (McConnachie et al., 1994; Nadabigengesere and Narasiah, 1998; Xuan-Thanh et al., 2019).

The results showed that powder from seed kernels of $M$. oleifera contains some natural coagulating properties at loading doses of 2, 4, 6, 8, $10 \mathrm{~g} / \mathrm{l}$ and above that have a similar effect as the conventional coagulation by alum. This lends support to earlier findings of the use of powder processed from Moringa seeds as a natural coagulant in water treatment plants (Ibrahim et al., 2015; Ashenafi et al., 2018; Xuan-Thanh et al., 2019).

Jar test depends on Moringa oleifera doses $(\mathrm{mg} / \mathrm{L})$ as natural coagulant with a chlorine dose $(5.0 \mathrm{mg} / \mathrm{L})$ to reduce algal count in Nile River, when the algal count was $5400 \mathrm{Unit} / \mathrm{mL}$ and turbidity was 9.33 NTU.

The highest algal count (200 Unit/ml) was recorded at $2 \mathrm{~g} / \mathrm{l}$ of Moringa oleifera dose, while the lowest algal count (160 Unit/ml) was recorded at $2.5 \mathrm{~g} / 1$ of Moringa oleifera doses, therefore the optimal dose of Moringa oleifera was chosen at $2.5 \mathrm{~g} / \mathrm{l}$, at this dose the percentage of algal removal was $97 \%$, residual chlorine satisfies for drinking water, increase TOC because overdose and low costs. $\mathrm{pH}$ values as a chemical agent ranged from 7.75 to 7.65 . Turbidity as a 
physical agent reduced from 9.33 NTU to 1.29 NTU (86.17\%). Residual alum was $0.08 \mathrm{mg} / \mathrm{l}$. Residual chlorine ranged from 1.8 to $1.9 \mathrm{mg} / \mathrm{l}$ (Table 4 ).

Table 4: Jar test depend on Moringa oleifera doses (from 0.5 to $3.0 \mathrm{~g} / \mathrm{l}$ ) and a chlorine dose $(5.0 \mathrm{mg} / \mathrm{l})$ in Nile River samples.

\begin{tabular}{lccccccc}
\hline \multicolumn{2}{c}{$\begin{array}{l}\text { Moringa oleifera }(\mathrm{g} / \mathrm{L}) \\
\text { Parameters }\end{array}$} & $\begin{array}{c}\mathbf{0 . 5} \\
(\mathbf{g} / \mathbf{L})\end{array}$ & $\begin{array}{c}\mathbf{1 . 0} \\
(\mathrm{g} / \mathbf{L})\end{array}$ & $\begin{array}{c}\mathbf{1 . 5} \\
(\mathrm{g} / \mathbf{L})\end{array}$ & $\begin{array}{c}\mathbf{2 . 0} \\
(\mathrm{g} / \mathrm{L})\end{array}$ & $\begin{array}{c}\mathbf{2 . 5} \\
(\mathrm{g} / \mathbf{L})\end{array}$ & $\begin{array}{c}\mathbf{3 . 0} \\
(\mathrm{g} / \mathrm{L})\end{array}$ \\
\hline Algal count & $(\mathbf{U n i t} / \mathbf{m L})$ & 200 & 190 & 180 & 170 & 160 & 160 \\
$\mathbf{p H}$ & & 7.75 & 7.75 & 7.75 & 7.70 & 7.70 & 7.65 \\
Turbidity & $(\mathbf{N T U})$ & 1.62 & 1.54 & 1.42 & 1.35 & 1.29 & 1.30 \\
Residual Alum & $\mathbf{( m g / L )}$ & 0.08 & 0.08 & 0.08 & 0.08 & 0.08 & 0.08 \\
Residual chlorine & $(\mathbf{m g} / \mathbf{L})$ & 1.8 & 1.8 & 1.8 & 1.8 & 1.8 & 1.9 \\
\hline
\end{tabular}

The impact of Alum coagulant doses $(28 \mathrm{mg} / \mathrm{l})$ upon the Algal removal in water pretreated with a dose of chlorine $(4.0 \mathrm{mg} / \mathrm{l})$ during algal peak period, the algal count $(650 \mathrm{Unit} / \mathrm{ml})$ was recorded, at this dose, the percentage of algal removal was $87.9 \%$. The turbidity (1.65 NTU) was noticed as a physical agent. Using $\mathrm{pH}$ values as a chemical agent showed that the $\mathrm{pH}$ value (7.3) was recorded. Residual alum $0.20 \mathrm{mg} / \mathrm{l}$ was recorded (the normal range should not exceed $0.2 \mathrm{mg} / \mathrm{l})$. Residual chlorine $1.5 \mathrm{mg} / \mathrm{l}$ was recorded, this residual chlorine satisfies for drinking water. EC $352(\mu \mathrm{s} / \mathrm{Cm})$ and TDS $232 \mathrm{mg} / 1$ were recorded. The data of $\mathrm{Mn}, \mathrm{Fe}$, chloride, sulfate, and TOC were obtained and explained in Table 5 and Figure 1. These results are agreement with Ahmed (2016) and Mohamed et al. (2020). 


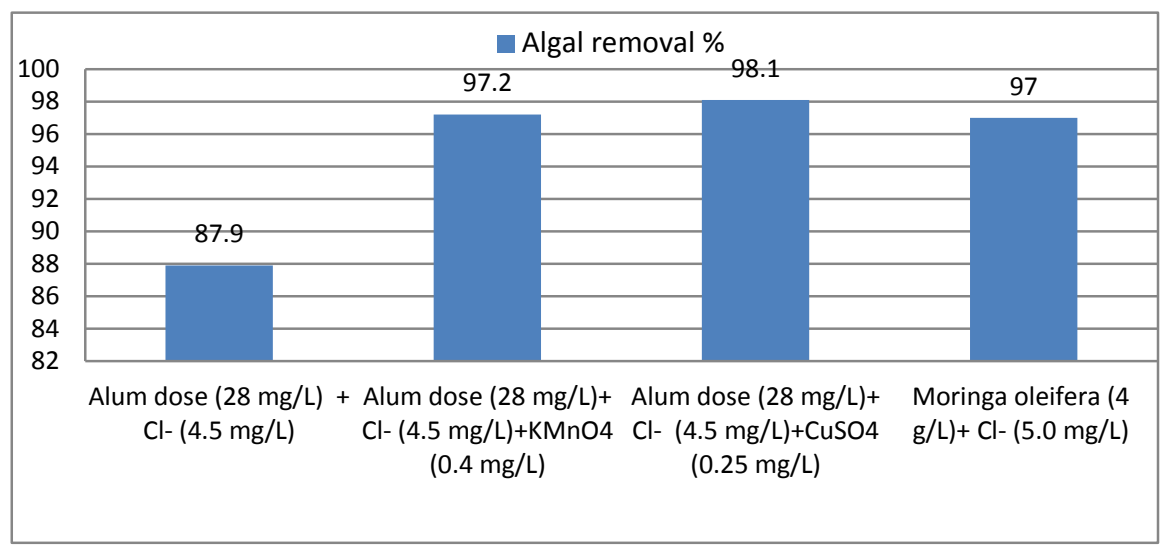

Fig. 1: Effect alum, pre-oxidation and Moringa oleifera algal removal \%

Water was pretreated with a combined per-oxidant permanganate $(0.4$ $\mathrm{mg} / \mathrm{l})$, dose of chlorine $(4.0 \mathrm{mg} / \mathrm{l})$ and alum coagulant doses $(28 \mathrm{mg} / \mathrm{l})$ during algal peak period, the algal count $(150 \mathrm{Unit} / \mathrm{ml})$ was determined, at this dose the percentage of algal removal was $97.2 \%$. The turbidity (1.43 NTU) was noticed as a physical agent. Using $\mathrm{pH}$ values as a chemical agent showed that the $\mathrm{pH}$ value (7.2) was measured. Residual alum $0.12 \mathrm{mg} / \mathrm{l}$ was noticed (the normal range should not exceed $0.2 \mathrm{mg} / \mathrm{l}$ ). Residual chlorine $2.5 \mathrm{mg} / \mathrm{l}$ was measured, this residual chlorine satisfies for drinking water. EC $392(\mu \mathrm{s} / \mathrm{Cm})$ and TDS $259 \mathrm{mg} / \mathrm{l}$ were recorded. The data of $\mathrm{Mn}, \mathrm{Fe}$, chloride, sulfate, and TOC were obtained and explained in Table 5 and Figure 1. These results are agreement with El-Dars et al. (2015). 
Nile water was pretreated with combined per-oxidant copper sulfate $(0.25 \mathrm{mg} / \mathrm{l})$, the dose of chlorine $(4.0 \mathrm{mg} / \mathrm{l})$, and alum coagulant doses $(28 \mathrm{mg} / \mathrm{l})$ during algal peak period, the algal count $(100 \mathrm{Unit} / \mathrm{ml})$ was measured, at this dose the percentage of algal removal was $98.1 \%$. The turbidity (1.32 NTU) was determined as a physical agent. Using $\mathrm{pH}$ values as a chemical agent showed that the $\mathrm{pH}$ value (7.25) was measured. Residual alum $0.14 \mathrm{mg} / \mathrm{l}$ was recorded (the normal range should not exceed $0.2 \mathrm{mg} / \mathrm{l}$ ). Residual chlorine $2.2 \mathrm{mg} / \mathrm{L}$ was measured, this residual chlorine satisfies for drinking water. EC $395(\mu \mathrm{s} / \mathrm{Cm})$ and TDS $261 \mathrm{mg} / \mathrm{l}$ were recorded. The data of Mn, Fe, chloride, sulfate, and TOC obtained are demonstrated in Table 5 and Figure 1. These results are in agreement with Mohamed et al. (2020).

The effect of Moringa oleifera seed (4 g/l) as a natural coagulant upon the Algal removal in water pretreated with a dose of chlorine $(5.0 \mathrm{mg} / \mathrm{l})$ during experiments, the algal count $(160 \mathrm{Unit} / \mathrm{ml})$ was recorded, at this dose, the percentage of algal removal was $97 \%$. The turbidity (1.29 NTU) was measured as a physical agent. Using $\mathrm{pH}$ values as a chemical agent showed that the $\mathrm{pH}$ value (7.6) was noticed. Alum $0.08 \mathrm{mg} / \mathrm{l}$ was recorded (the normal range should not exceed $0.2 \mathrm{mg} / \mathrm{l})$. Residual chlorine $1.5 \mathrm{mg} / \mathrm{l}$ was noticed, this residual chlorine satisfies for drinking water. EC $334(\mu \mathrm{s} / \mathrm{Cm})$ and TDS $220.4 \mathrm{mg} / 1$ were determined. The data of Mn, Fe, chloride, sulfate, and TOC were obtained and explained Table 6 and Figure 1. These results are agreement with Ibrahim et al., (2015). Moringa oleifera dose between 2 and $8 \mathrm{~g} / \mathrm{l}$ was effective to reduce water turbidity from $9.33 \mathrm{NTU}$ to $1.29 \mathrm{NTU}(86.17 \%)$. It was observed that applying M.O. between 2 and $8 \mathrm{~g} / \mathrm{L}$ to the pre-chlorinated waters achieved a primary algal removal efficiency of $97 \%$ for the number of algae. These results are in agreement 
with Ashenafi et al. (2018) who stated that $M$. oleifera decreased water turbidity to about $86.98 \%$.

Globulin and albumin were the highest protein content in the seeds of $M$. oleifera between 53 and $44 \%$. Using protein profile analysis showed that the main protein domains have molecular weights of about 6.5 and $9.0 \mathrm{kDa}$, respectively. So, the scientific information about the coagulant active ingredients in $M$. oleifera seeds, experiments use to improve the extraction of these components (XuanThanh et al., 2019).

Table 5: The effect of Alum coagulant and chlorine dose with a combined per-oxidant on water characteristics.

\begin{tabular}{|c|c|c|c|c|c|}
\hline \multirow{2}{*}{ Parameters } & \multirow{2}{*}{ Unite } & \multirow{2}{*}{$\begin{array}{l}\text { Nile water } \\
\text { sample }\end{array}$} & \multicolumn{3}{|c|}{$\begin{array}{l}\text { Alum coagulant doses }(28 \mathrm{mg} / \mathrm{l}) \text { and chlorine } \\
\text { dose }(4.0 \mathrm{mg} / \mathrm{l}) \text { with a combined pre-oxidant }\end{array}$} \\
\hline & & & $\begin{array}{l}\text { Alum dose } \\
(28 \mathrm{mg} / \mathrm{l})\end{array}$ & $\begin{array}{l}\text { Permanganate } \\
(0.4 \mathrm{mg} / \mathrm{l})\end{array}$ & $\begin{array}{l}\text { Copper sulfate } \\
(0.25 \mathrm{mg} / \mathrm{l})\end{array}$ \\
\hline Algal count & Unit/ml & 5400 & 650 & 150 & 100 \\
\hline Algal removal & $\%$ & - & 87.9 & 97.2 & 98.1 \\
\hline Turbidity & NTU & 9.33 & 1.65 & 1.43 & 1.33 \\
\hline pH & - & 8.1 & 7.3 & 7.2 & 7.25 \\
\hline Residual Alum & $\mathrm{mg} / \mathrm{L}$ & 0.07 & 0.20 & 0.12 & 0.14 \\
\hline $\begin{array}{l}\text { Residual } \\
\text { Chlorine }\end{array}$ & $\mathrm{mg} / \mathrm{L}$ & - & 1.5 & 2.5 & 2.2 \\
\hline EC & $\mu \mathrm{s} / \mathrm{Cm}$ & 328.7 & 352 & 392 & 395 \\
\hline TDS & $\mathrm{mg} / \mathrm{L}$ & 216.9 & 232 & 259 & 261 \\
\hline Residual Mn & $\mathrm{mg} / \mathrm{L}$ & ND & ND & 0.1 & 0.02 \\
\hline Residual Fe & $\mathrm{mg} / \mathrm{L}$ & 0.19 & ND & ND & ND \\
\hline Chloride & $\mathrm{mg} / \mathrm{L}$ & 23 & 27 & 28 & 28 \\
\hline Sulfates & $\mathrm{mg} / \mathrm{L}$ & 21.8 & 32.4 & 31.9 & 36.8 \\
\hline TOC & $\mathrm{mg} / \mathrm{L}$ & 4.52 & 6.6 & 6.4 & 6.5 \\
\hline
\end{tabular}


Table 6: The effect Moringa oleifera as a coagulant and chlorine dose on water characteristics.

\begin{tabular}{lccc}
\hline \multicolumn{1}{c}{ Parameters } & Unite & Nile water sample & $\begin{array}{c}\text { Moringa oleifera (25 mg/l) as coagulant } \\
\text { with a chlorine dose } \mathbf{( 5 . 0} \mathbf{~ m g / l )}\end{array}$ \\
\hline Algal count & Unit/ml & 5400 & 160 \\
Algal removal & $\%$ & - & 97 \\
Turbidity & $\mathrm{NTU}$ & 9.33 & 1.29 \\
pH & - & 8.1 & 7.8 \\
Residual alum & $\mathrm{mg} / \mathrm{L}$ & 0.07 & 0.07 \\
Residual & $\mathrm{mg} / \mathrm{L}$ & - & 1.8 \\
chlorine & & & \\
EC & $\mu \mathrm{s} / \mathrm{Cm}$ & 328.7 & 334 \\
TDS & $\mathrm{mg} / \mathrm{L}$ & 216.9 & 220.4 \\
Residual Mn & $\mathrm{mg} / \mathrm{L}$ & $\mathrm{ND}$ & $\mathrm{ND}$ \\
Residual Fe & $\mathrm{mg} / \mathrm{L}$ & 0.19 & 0.08 \\
Chloride & $\mathrm{mg} / \mathrm{L}$ & 23 & 28 \\
Sulfates & $\mathrm{mg} / \mathrm{L}$ & 21.8 & 22.0 \\
TOC & $\mathrm{mg} / \mathrm{L}$ & 4.52 & 6.8 \\
\hline
\end{tabular}

\section{Conclusion}

This study concluded that algal removal from Nile water may be more or less easy, depending on the nature of the prevailing group. On the other hand, treatment plants must modify their treatment method according to the numbers and types of algal groups to provide an aesthetically acceptable and biologically safe supply of water. Also, the application of per-oxidant such as permanganate or copper sulfate with alum coagulant dose is efficient on algal removal. Using peroxidant with alum dose in jar test leads to the reduction of residual chemicals, alum dose, and chlorine dose which used in water treatment plants. So, this has a big role economically and more safe for people health. Also, Moringa oleifera 
was used as a natural coagulant because it contains a coagulant protein in Jar test instead of alum; M. oleifera is safer for people health, with no residual alum, and low cost in the water treatment plants.

\section{References}

Abd El-Hady H.H. (2014). Alternations in biochemical structures of phytoplankton in as wan reservoir and river Nile, Egypt. Journal of Biodiversity and Environmental Sciences (JBES), 4(2), 68-80.

Abou El Ella S.M., Hosny M.M. and Bakry M.F. (2007). Growth inhibition of bloom-forming using rice straw in water courses (case study), in proceedings of the eleventh International Water Technology Conference, IWTC11 2007 Sharm El-Sheikh, Egypt, 105-112.

Ahmed A. H. A. (2016). Study the microbiological effects on chemical doses and water treatment engineering. M.Sc. thesis, faculty of science, Fayoum University.

Amagloh F. K. and Benang A. (2009). Effectiveness of Moringa oleifera seed as coagulant for water purification. African Journal of Agricultural Research 4 (1), 119-123.

APHA, American Public Health Association, (2005). Standard Methods for Examination of Water and Waste water (21st Edition), Washington D.C., USA, American Public Health Association.

APHA, American Public Health Association, (2012). Standard methods for the examination of water and wastewater, $22^{\text {nd }}$ Edition. 
Ashenafi Delelegn, Samuel Sahile and Azamal Husen (2018). Water purification and antibacterial efficacy of Moringa oleifera Lam. Agriculture \& Food Security, 7:25.

Badawy M.I., Gad-Allah T.A., Ali M.E.M. and Yoon Y. (2012). Minimization of the formation of disinfection by products. Chemosphere, 89, 235.240.

Babel S. and Takizawa S. (2011). Chemical pretreatment for reduction of membrane fouling caused by algae. Desalination, 274, 171-176.

Bulusu K.R. and Sharma V.P. (1967). Significance of point of application of a coagulant in jar test. Environ. Health (India), 9: 339.

Carkal D. PFRA (2002). Copper treatments for Dugouts. Agriculture and Agrifood Canada. March, 2002.

Chen J.J. and Yeh H.H. (2005). The mechanisms of potassium permanganate on algae removal. Water Research, 39, 4420-4428.

Chen J.J., Yeh H.H. and Tseng I.C. (2009); Effect of ozone and permanganate on algae coagulation removal. Pilot and bench scale tests. Chemosphere, 74, 840-846.

Cohen J.M. (1957). Improved Jar-test. J. AWWA, 49: 1427-1431.

Devrimci H.A., Yuksel A.M., Sanin F.D. (2012); Algal alginate: Apotential coagulant for drinking water treatment. Desalination, 299, 16-21.

Donia N. (2007). Survey of potable water quality problems in Egypt, In Proceedings of Eleventh International Water Technology Conference, IWTC11 2007 Sharm El-Sheikh, Egypt, 1049-1058. 
El-Dars F.M.S.E., Abdel-Rahman M.A.M., Salem O.M.A., and Abdel-Aal E.A. (2015). Algal control and enhanced removal in drinking waters in Cairo, Egypt: A case study. Environmental Science an Indian Journal. ESAIJ, 10(8), 295-307.

El-Shinnawy I.A., Abdel-Meguid M., Nour Eldin M. M. and Bakry M.F. (2000). Impact of Aswan High Dam On The Aquatic Weed Ecosystem, ICEHM2000, Cairo University, Egypt, 534- 541.

Fan J., Daly R., Hobson P., Ho L. and Brookes J. (2013). Impact of potassium permanganate on cyanobacterial cell integrity and toxin release and degradation. Chemosphere, 92, 529.534.

Gao S., Du M., Tian J., Yang J., Yang J., Ma F. and Nan J. (2010). Effects of chloride ions on electro coagulation-flotation process with aluminum electrodes for algae removal. Journal of Hazardous Materials, 182, 827834.

Gautam K. N. and Vikram S.G. (2011). Removal of Janus Green dye from aqueous solution by phosphoric acid carbonized agroindustrial waste. Science Asia 37: 38-42.

Gassenschmidt U., Jany K.D., Tauscher B. and Niebergall H. (1995). Isolation and characterization of a flocculating protein from Moringa oleifera Lam. Biochem .Biophyhs. Acta Gen. Subj., 1243: 477-481.

Heng L., Jun N., Wen-jie H. and Q. Guibai L. (2009). Algae removal by ultrasonic irradiation. Coagulation. Desalination, 239, 191-197.

Heng L., Yanling Y., Weijia G., Xing L. and Guibai L. (2008). Effect of pretreatment by permanganate/chlorine on algae fouling control for ultrafiltration (UF) membrane system. Desalination, 222, 74-80. 
Henderson R., Parsons S.A. and Jefferson B. (2008). The impact of algal properties and pre-oxidation on solid. Liquid separation of algae. Water Research, 42, 1827-1845.

Ibrahim W. M., Essa A. M.M. and Abouzied A. H. (2015). Application of biological agent to determine the optimal coagulant dose in water treatment plants. The African Journal of Mycology and Biotechnology. 20 (1), 31-45.

Jahn S.A.A. (1988). Using Moringa seeds as coagulants in developing countries. J. AWWA, 90:43-50.

James W. and Conrad D. (2004). Evaluating treatment processes for removing cyanobacterial toxins from drinking water supplies, The Water Research Users Group, Alberta Environment, Alberta Research Council, 44.

Ma J. and Liu W. (2002). Effectiveness and mechanism of potassium ferrate (VI) pre-oxidation for algae removal by coagulation. Water Research, 36, 871-878.

Manahan S., (2000). Environmental chemistry, 7th Edition Lewis Publishers, London.

McConnachie G., Mtaweli A. and Young R. (1994). Design Aspects of Hydraulic Flocculator, pp: 284-288. In Proc. 20th WEDC Conference, Colombo, Srilanka.

Mohamed F. M., El-Deen F. N., Kamal A. M. (2020). The Relationship between Algal Counting and Chemicals Consumption of Conventional Purification Systems at Qena Governorate, Egypt. Egyptian Journal of Aquatic Biology \& Fisheries; 24(1): 161 - 172. 
Nadabigengesere A. and Narasiah K.S. (1998). Quality of water treated by coagulation using Moringa oleifera seeds. Water Research, 32(3): 781791.

Nadabigengesere, A., Narasiah K.S. and Talbot B.G. (1995). Active agents and mechanism of coagulation of turbid waters using Moringa oleifera. Water Research, 29: 703-716.

Purbonegoro T., Suratno, Puspitasari R., and Husna N. A. (2018). Toxicity of copper on the growth of marine microalgae Pavlova sp. and its chlorophyll-a. IOP Conf. Series: Earth and Environmental Science 118 (2018) 012060.

Raman K. and Raman B.C. (1990). GUIDELINES FOR APPLYING COPPER SULFATE AS AN ALGICIDE. ILENR/RE-WR-88/19. Reprinted: April 1990.

Reckhow D.A., Singer P.C. and Trussell R.R. (1986). Ozone as a coagulant aid, Proc. 1986 AWWA Conf. Denver, Colo.

Shen Q., Zhu J., Cheng L., Zhang J., Zhang Z. and Xu X. (2011). Enhanced algae removal by drinking water treatment of chlorination coupled with coagulation, Desalination, 271, 236-240.

Shehata S.A., Ali G.H. and Wahba S.Z. (2008). Distribution pattern of Nile water algae with reference to its treatability in drinking water. Journal of Applied Sciences Research, 4(6), 722-730. 
Usepa (1999). Potassium Permanganate, Alternative disinfectants and oxidants: EPA guidance manual USEPA, OW, Office of groundwater and drinking water EPA8 15-R-99-014, 815-R-99-014, http://www.epa.gov/ogwdw/mdbp/alternative_disinfectants_guidance.pdf, 5, 1-5.15.

Wang L., Qiao J., Hu Y., Wang L., Zhang L., Zhou Q. and Gao N. (2013). Pre-oxidation with $\mathrm{KMnO} 4$ changes extracellular organic matter's secretion characteristics to improve algal removal by coagulation with a low dosage of poly aluminium chloride. Journal of Environmental Sciences, 25(3), 452.459.

WHO (2011). Measuring chlorine levels in water supplies, Technical notes on drinking-water, Sanitation and hygiene in emergencies 11, WHO/Water Engineering Development Center, http://www.who.int/water_sanitation_health/publications/2011/tn11_chlor ine_levels_en.pdf?ua=1(accessedMay 29, 2014).

Xuan-Thanh Bui, Chart Chiemchaisri, Takahiro Fujioka and Sunita Varjani (2019). Water and Wastewater Treatment Technologies. Energy, Environment, and Sustainability. ISBN 978-981-13-3259-3 (eBook). https://doi.org/10.1007/978-981-13-3259-3.

Yanxia Zhao, Huiqing Lian, Chang Tian, Haibo Li, Weiying Xu, Sherub Phuntsho, Kaimin Shih (2021). Surface water treatment benefits from the presence of algae: Influence of algae on the coagulation behavior of polytitanium chloride. Environ. Sci. Eng., 15(4): 58.

Zeta-Meter, Inc., (1993). Coagulation and Flocculation. Zeta-Meter, Inc., Fourth Edition, April 1993. 


\title{
تطبيق البرمنجنات، وكبريتات النحاس مع جرعة الشبة وإستخدام بذور المورينجا

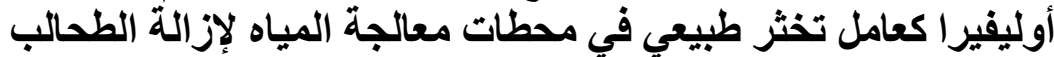

\author{
عادل حسين أبوزيد أحمد' ، حنان عبدالله سعيد حسان' \\ ا - الدعامل المركزية - الثركة القابضة لمباه الثرب والصرف الصحي - جيزة - مصر \\ r - قسم النبات والمبكروبيولوجي ـ كلية العلوم - جامعة الفبوم - مصر.
}

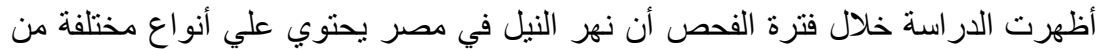

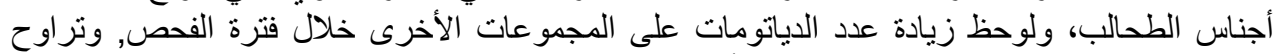

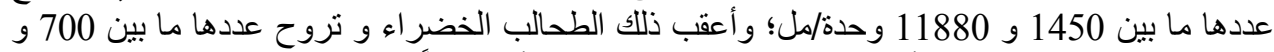
1220 وحدة/مل, كما لوحظ أن الطحالب الخضراء المزرقة أقل عدداً و تراوحت ما بـ بين 160 و 703

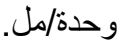

و تتم معالجة مياه النيل بإستخدام نو عين من المخثرات الكيميائية، و هي كبريتات الألومنيوم

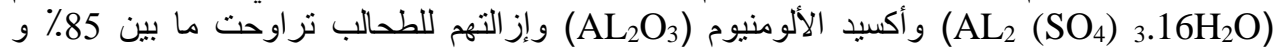
90٪، على التو الي، و بعد إضافة جر عة البرمنجنات (AMNO

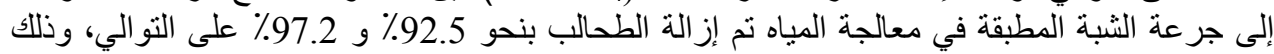

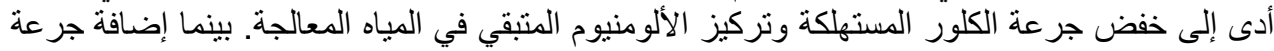
كبريتات النحاس كعامل مؤكسد (CUSO

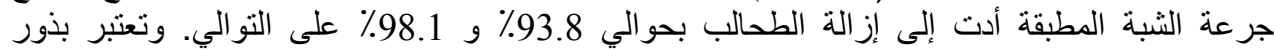

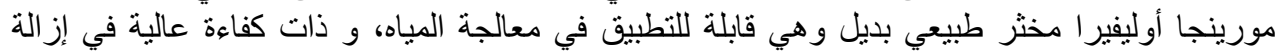

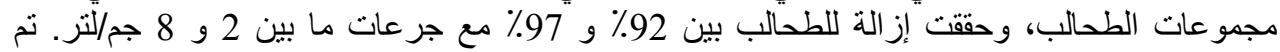

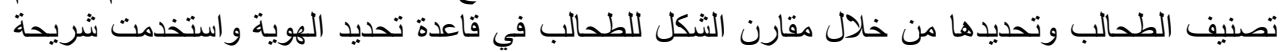
العد Sedgwick-Rafter لحساب عدد الطحالب. 